\section{Problem Based Learning and the Stricto Sensu Postgraduate Education: proposal for the Masters in Mother and Child Health curriculum at the Instituto Materno Infantil Professor Fernando Figueira-IMIP, Recife, Brazil, 2007}

\section{Aprendizagem Baseada em Problemas e a Pós-graduação Stricto Sensu: proposta para o currículo do Mestrado em Saúde Materno Infantil do Instituto Materno Infantil Professor Fernando Figueira-IMIP, Recife, Brasil, 2007}

Gilliatt Falbo ${ }^{1}$

João Guilherme Bezerra Alves²

Isabella Samico ${ }^{3}$

Maria do Carmo M. B. Duarte

José Eulálio Cabral Filho ${ }^{5}$

Melania Maria Ramos de Amorim ${ }^{6}$

Kátia Virgínia de Oliveira Feliciano ${ }^{7}$

José Natal Figueiroa ${ }^{8}$

Jailson de Barros Correia ${ }^{9}$

1-3 Diretoria de Ensino. Pós-Graduação Stricto Sensu em Saúde Materno Infantil. Instituto Materno Infantil Prof. Fernando Figueira-IMIP e Escola Pernambucana de Saúde FBV-IMIP, Recife, PE, Brasil.

4-9 Diretoria de Ensino. Pós-Graduação Stricto Sensu em Saúde Materno Infantil. Instituto Materno Infantil Prof. Fernando Figueira-IMIP. Rua dos Coelhos, 300. Recife, PE, Brasil. CEP: 50.070-550. E-mail: mestrado@imip.org.br

\section{Introduction}

Learning is a complex process understood as the acquisition, broadening and or improvement of knowledge, capabilities, skills and attitudes. ${ }^{1}$ Demo $^{2}$ considers learning as a reconstructive phenomenon, in the sense that one learns from what has been learned before and draws knowledge from what is already known. To Freire, ${ }^{3}$ teaching is not the mere transfer of knowledge but the creation of the possibilities for its construction, so the learning process requires ownership of what has been learned, conversion into what is apprehended and its reinvention.

In the teaching and learning process, the update of teaching practices and the participation of students need to be encouraged, so to learn to operate correctly, to raise doubts and investigate, to acquire the skill to always learn, to apprehend issues of global and local concern, to better understand the world and to better understand the other. Thus there is a need for change in the traditional way of teaching, indicating how relevant is to consider the student as a partner and to be clear about intended objectives. ${ }^{4,5}$

Active learning has therefore an important role as a tool for building a critical and reflective knowledge and Problem Based Learning (PBL) is one of its different types. Adult learning assumptions are at the core of PBL: previous knowledge and experience mediate new acquisitions, the value of daily practice as the structure for learning and the understanding that motivation to learn comes from personal projects and the social and educational conditions. ${ }^{6,7}$
PBL considers a problem-case or scenario as a way to stimulate the discussion of a given topic in the form of a tutorial group. The participants define learning objectives, go through individual studies and then return to the group for a final discussion. Besides the acquisition of knowledge, tutorial group learning strengthens communications skills, teamwork, the responsibility of one's own learning and mutual respect. ${ }^{8,-11}$

The PBL method has been adopted in many educational institutions worldwide, particularly for undergraduate courses on medicine, nursing, pharmacy and others at universities such as Maastricht in the Netherlands, Liverpool in England, McMaster and Montreal in Canada and New Mexico in the USA. ${ }^{6,12}$ In Brazil, there has been experience with this method in undergraduate courses, particularly in the health sciences, at institutions like the State University of Londrina, Paraná, the Marília Faculty of Medicine, São Paulo, the State University of Brasília and the Pernambuco School of Health FBVIMIP. Likewise, some initiatives using active learning methodologies have been reported in lato sensu postgraduate education such as medical and multi-professional residency programs (Department of Community and Family Medicine-Duke University Medical Center-Ostbye, 2004) and, in Brazil, specialization courses at the Ceará School of Public Health. $6,13-15$

Some experiences in the use of PBL for stricto sensu postgraduate programs in the health sciences have been acknowledged around the world, such as at McMaster and Maastricht Universities. ${ }^{16,17}$ However, according to the reviewed literature, no 
PBL-based stricto sensu postgraduate programs are found in Brazil.

In 2006, PBL-based medical and health sciences curricula were successfully implemented at the Pernambuco School of Health FBV-IMIP. ${ }^{13}$ Together with the good performance of IMIP's stricto sensu postgraduate program (CAPES grade 4), this lead to the decision to adopt a PBL-based curriculum for IMIP's Masters in Mother and Child Health course.

Moreover, taking into account the fact that one of the aims of a Masters course is to provide teaching practice, it was considered strategic to move from a receptive to an active learning environment, with the aim of overtaking simplistic methods of "acquisition of prescribed contents" trough a process of permanent and active education. $^{2}$

This paper aims to describe the proposal and strategies for implementation of a new, PBL-based curriculum for the Masters in Mother and Child Health course at the Instituto Materno Infantil Prof. Fernando Figueira-IMIP.

\section{The conception of a new curriculum for the Masters course}

The stricto sensu postgraduate program on Mother and Child Health was conceived in 1993, as an innovative teaching and research proposal for the Northeastern region of Brazil. The course was based on the Masters developed at the Institute of Child Health-University of London. After 14 years of consolidating experience, a new problem-based curriculum was proposed in 2006 at the postgraduate academic board planning meeting.

In the beginning of the process, during the first half of 2007, weekly meetings took place. Participants were researchers and professors from IMIP's postgraduate program and a task force worked on the preparation and validation of the new curriculum proposal.

The steps for preparing and carrying out a research project and reporting its findings in the form of scientific papers were considered as the directing, central axis for the new Masters curriculum development. Together with core specific knowledge and its transmission, these are the basic requirements for obtaining a Masters degree. The curriculum was built in the shape of modules. Each module had its specific aims, learning objectives and scenarios thoroughly discussed within the task force and then summarized and sent for critical review to all members of the stricto sensu postgraduate aca-demic board. A final consensus was obtained in a special, extraordinary meeting of the board.

\section{Establishing a proposal for implementa- tion of the Problem Based Learning method}

Following the conception of the directing, core axis (Table 1), the new curricular structure was established with a minimum of 62 credits, 42 of which corresponding to the following modules: $1^{\text {st }}$ ) "The Question", lasting for six weeks; $2^{\text {nd }}$ ) "The conceptual framework", with seven weeks; $3^{\text {rd }}$ "The Instrument", with seven weeks; $4^{\text {th }}$ ) "Results and Analysis", with five weeks and $5^{\text {th }}$ ) "The Product and the Transmission of Knowledge", with four weeks. The time in the classroom or laboratory will consist of 450 load hours and induced studies will make 180 load hours minimum (each credit equals 15 load hours). Twenty credits are allocated for preparing the dissertation. Overall, the course will have a minimum of 930 load hours.

The standard week will consist of three tutorial group meetings, each one with a case opening and closure; two computer laboratory sessions and induced studies (Table 2). The group will be made of 15 students divided into two simultaneous tutorial groups. The tutorial groups will follow the seven steps of Problem Based Learning. ${ }^{8,11}$

The formative and summative assessments consider cognitive, psychomotor and emotional aspects of students' performance in a continued and systematic way. The performances will be measured and recorded. Formative assessment takes into account tutor, student and program perspectives and consist of: Assessment of the Student by the Tutorial Group Tutor; Assessment of the Tutorial Group Tutor by the Student; Assessment of the Student by the Computer Laboratory Tutor; Assessment of the Computer Laboratory Tutor by the Student; SelfAssessment; Peer Assessment; Assessment of the Module by the Student. Meanwhile, summative assessment will be considered at the end of each module and will consist of: a) module 1: an essay on the study topic (object, rationale and directing research question); b) module 2: an essay with the literature review on the topic studied; c) module 3 : project qualifying examination; d) module 4: preliminary internal academic board examination; e) module 5: assessment of dissertation based on the scientific papers produced. 
Table 1

Modules and objectives of the new Problem Based Learning-based curriculum. Masters in Mother and Child Health-Instituto Materno Infantil Prof. Fernando Figueira-IMIP. Recife, Pernambuco, Brazil, 2007.

\begin{tabular}{|c|c|c|c|c|}
\hline First module & Second module & Third module & Fourth module & Fifth module \\
\hline \multirow[t]{3}{*}{ THE QUESTION } & THE CONCPTUAL & THE INSTRUMENT & RESULTS AND & THE PRODUCT AND \\
\hline & FRAMEWORK & & ANALYSIS & TRANSMISSION OF \\
\hline & & & & KNOWLEDGE \\
\hline
\end{tabular}

\section{General aim}

At the end of the module the Masters students are expected to be able to formulate a socially relevant research question within the areas of expertise of IMIP.

\section{General aim}

At the end of the module the students are expected to be capable to search international databases for relevant papers and to carry out narrative and systematic reviews of the literature.

General aim
At the end of the module the
students are expected to be
able to design a research
project which is appropriate to
answer their research
questions.

\section{General aim}

At the end of the module the students are expected to be able to critically assess the results of their studies.

\section{General aim}

At the end of the module the students are expected to be able to assess, communicate and discuss with the scientific community about their findings, in the form of findings, in the form of publications.

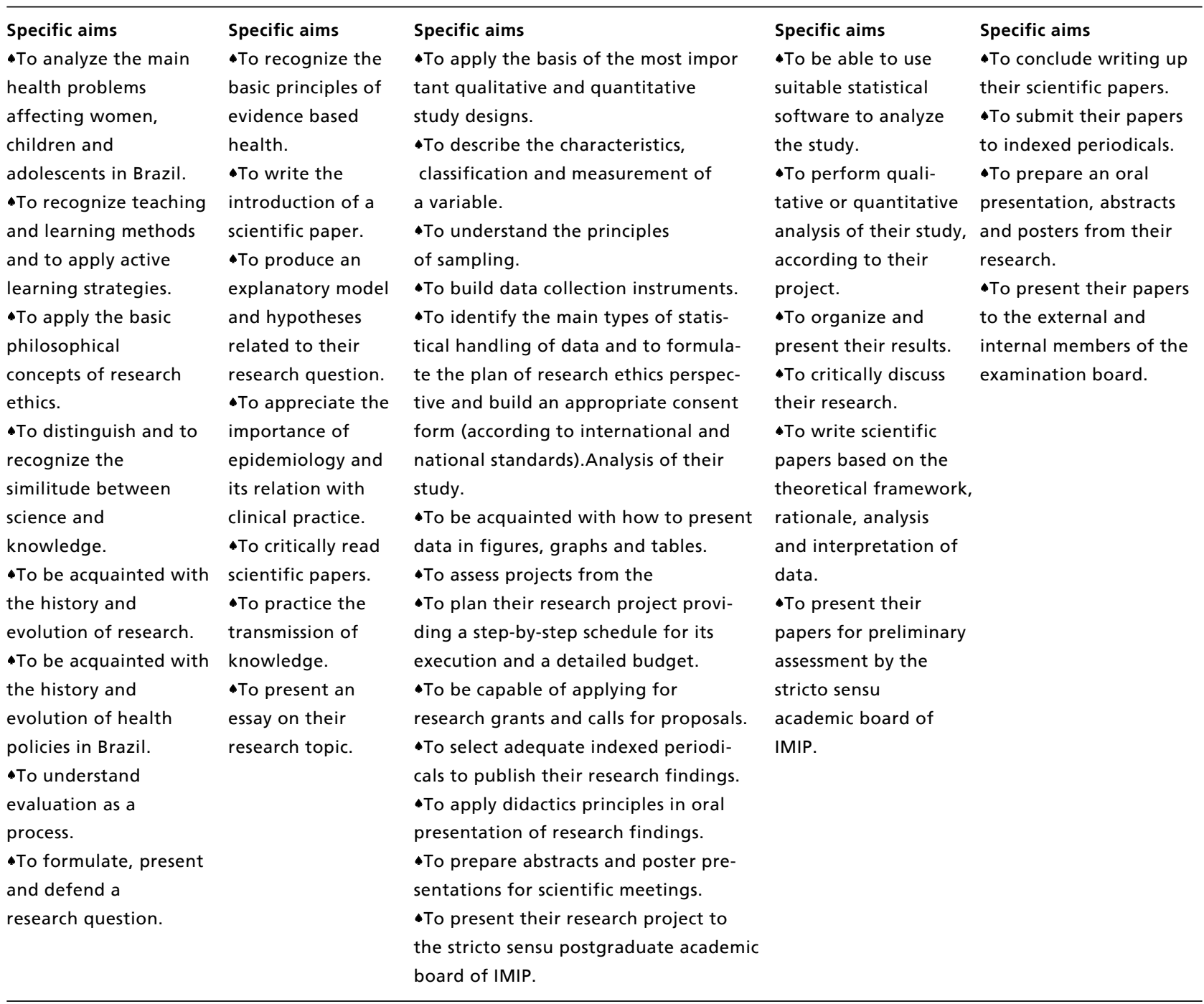


Standard week. Masters in Mother and Child Health- Instituto Materno Infantil Prof. Fernando Figueira-IMIP. Recife, Pernambuco, Brazil, 2007.

\begin{tabular}{|c|c|c|c|c|c|}
\hline Time & Monday & Tuesday & Wednesday & Thursday & Friday \\
\hline $8 h-9 h$ & Tutorial & Laboratory & Tutorial & Laboratory & Tutorial \\
\hline $9 h-10 h$ & Tutorial & Laboratory & Tutorial & Laboratory & Tutorial \\
\hline $10 h-11 h$ & Tutorial & Laboratory & Tutorial & Laboratory & Tutorial \\
\hline $11 \mathrm{~h}-12 \mathrm{~h}$ & Tutorial & Laboratory & Tutorial & Laboratory & Tutorial \\
\hline $14 \mathrm{~h}$ to $21 \mathrm{~h}$ & \multicolumn{5}{|c|}{ Three hours / day for induced individual studies } \\
\hline
\end{tabular}

\section{The Process of Implementation of PBL methodology}

\section{First phase: training the tutors}

In the second semester of 2007, professors from IMIP's stricto sensu postgraduate program underwent theoretical and practical training on PBL methodology to become tutors. The contents of the training included topics such as: Active Learning Methodology; New Skills for the University Professor; Reflecting on Mentor; Bloom's Taxonomy; Evaluation and Assessment Processes; Problem Based Learning; PBL Simulation; Practical Observation of Group Tutorials at the Pernambuco School of Health FBV/IMIP.

\section{Second phase: academic implementation}

The course will start in March 2008 and regular monitoring meetings will take place during the whole academic year, in order to assess and eventually make adjustments to the curriculum.

\section{References}

1. Souza VT. Avaliação da aprendizagem. Ensaio: Aval Pol Públicas Educ. 1994; 1: 13-20.

2. Demo P. Conhecer e aprender. Sabedoria dos limites e desafios. Porto Alegre: Artmed; 2000.

3. Freire P. Pedagogia da autonomia - Saberes necessário à prática educativa. São Paulo: Paz e Terra; 2004.

4. Arruda BKG, Arruda IKG. A educação profissional em saúde e a realidade social. In: Educação Médica: a importância de fortalecer os elos entre ensino, pesquisa e ação. Recife: IMIP, Ministério da Saúde; 2001.

5. Arruda BKG. Ensino de vanguarda. In: Costa MCMA, Arruda IKG, Asfora MY, organizadores. Escritos inspirados pelas circunstâncias. Recife: Liceu; 2007. p. 159-61.

\section{Final comments}

The Masters in Mother and Child Health curriculum reformulation arises within an encouraging institutional momentum, following positive assessment of undergraduate and postgraduate courses at masters and doctorate levels. The proposal is innovative for stricto sensu postgraduate programs in Brazil and is in tune with the Ministry of Education curricular guidelines. The new curriculum considers all potential gains of active learning, is student-centered and promotes reflection, students'participation and teachers'continued education. ${ }^{3,4}$ It is a holistic educational proposal comprising better capability to develop teaching through active learning methods. Furthermore, the new curriculum proposal is a challenging and relevant enterprise which aims to contribute to the development of professional education at undergraduate and postgraduate levels.

6. Batista N, Batista SH, Goldenberg P, Seiffert O, Sonzogno MC. O enfoque problematizador na formação de profissionais da saúde. Rev Saúde Pública. 2005; 39: 231-7.

7. Kaufman DM. ABC of learning and teaching in medicine applying educational theory in practice. Br Med J. 2003; 326: 213-6.

8. Wood D. ABC of learning and teaching in medicine Problem Based Learning. Br Med J. 2003; 326: 328-30.

9. Rhodes DG. A practical approach to Problem Based Learning: simple technology makes PBL accessible. Am J Pharm Educ. 1999; 63:410-4.

10. Malbrán MC. La tutorial en el nível universitario. Rev Inform Educ Médios Audiovis. 2004; 1: 5-11. 
11. Kilroy DA. Problem Based Learning. Emerg Med J. 2004; 21: 411-3.

12. Vimla LP, Arocha JF, Branch T, Karlin DR. Relationship between small group problem-solving activity and lectures in health science curricula. J Dent Educ. 2004; 68: 1058-80.

13.FBV (Faculdade Boa Viagem), IMIP (Instituto Materno Infantil de Pernambuco). Projeto Político Pedagógico. Recife; 2005.

14. Ostbye T, Krause KM, Gradison M, Eisenstein EL, Wagner GS. A problem-based approach to teaching outcomes research in family medicine residency. Fam Med. 2004; 36: $470-2$.

Submitted on May 21, 2007

Final version submitted on September 10, 2007

Aproved on October 15, 2007
15. Soares SMS, Serapioni M, Caprara A. A Aprendizagem Baseada em Problemas na pós-graduação - a experiência do Curso de Gestores de Sistemas Locais de Saúde no Ceará. Rev Bras Educ Med. 2001; 25: 54-61.

16.Universiteit Maastricht. Prospective master's students Problem-Based Learning. Disponível em URL: http://www. unimaas.nl/pbl/[2007 Out 17].

17. McMaster University. Programmes in Health Sciences. Available from: URL: http://wwwfhs.mcmaster.ca/grad/ nursing/proginfo.htm [2007 Oct 17]. 